之をハァトリ・ベリー氏法 (Hart'y-Baly method)に依りて示せば第 3〜4 圖の如L。

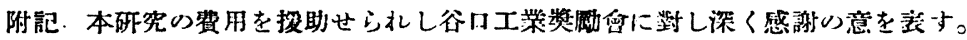

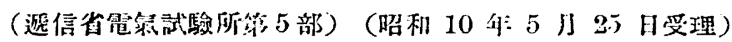

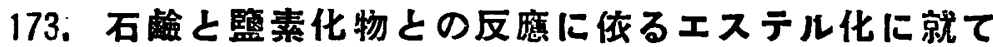

山田真 $\vec{i} \hat{i}$

天然に産する油脂類は 3 價エステルであるが 4 便アルコールであるェリトリットと亞麻仁油酸とのエステ

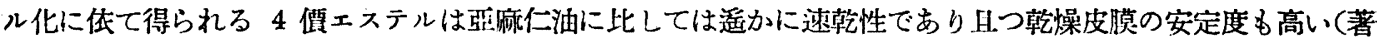

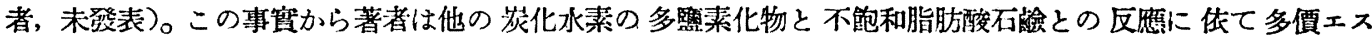

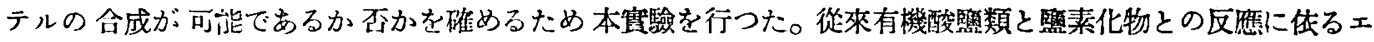

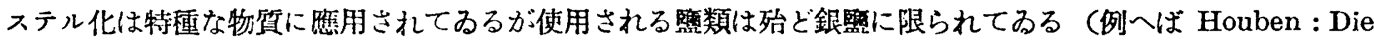
methoden der organischen ( hemic, 3 Auflage, 657 參照)。これは他の金屬擥類例へばアルカリ監類の如 きものからは艮好な收量でェステルを作得ないことに依るのであららが，著者は工業的見地より考へて銀

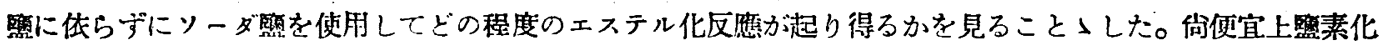
物の訊料としては罱素化程度の低いものを用ひた。

1. 倵料

試料石险 試料石险としてはステアリン酸ソーダオンイン酸ソーダ及ナフテン酸ソーダを用ひた。前 2 者 は䳌和及不能和の影響を見るのが目的である。何れも市販の脂肪酸及ナフテン酸をその嫿使用しこれらをアル

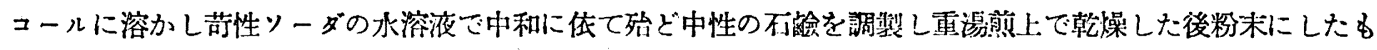
のである。但しナフテン酸ソーダは乾燥狀態でもグリース狀を是してるた。これらの不蝓の $\mathrm{KOH}$ 當量 (便宜 上左の如く呼ぶ）は次表の如くである。

第 1 表 石塈 の $\mathrm{KOH}$ 當 量

$\begin{array}{cc}\text { 測定値 } & \text { 理論值 } \\ 182.0 & 182.4 \\ 183.1 & 183.6 \\ 157.8 & -\end{array}$

上記の $\mathrm{KOH}$ 當量とは $\frac{\mathrm{KOH} \text { 分子量 }}{\text { 石崄分子量 }} \times 1000$ を表はすむのでむつて, その測定估は $1 \mathrm{~g}$ の石羷を $50 \mathrm{cc} の$ 水に浴解しメチル・オレンヂを指示葬として $0.2 N$ の $\mathrm{HCl}$ で逊定し, 消費された $\mathrm{HCl}$ 量老 $\mathrm{KOH}$ の $\mathrm{mg}$ 數 に掺算したものである。

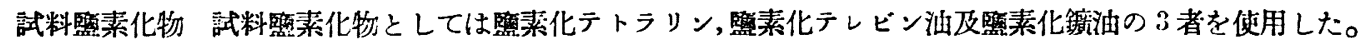

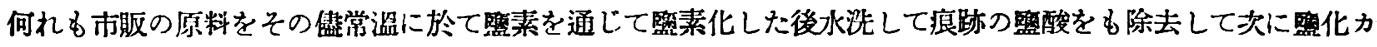

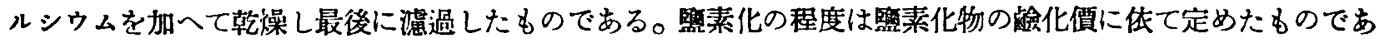
つて第 2 表に示寸如くである。

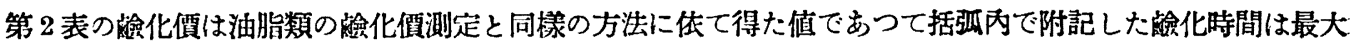

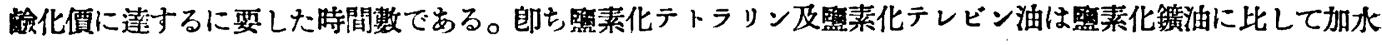

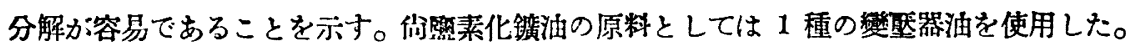




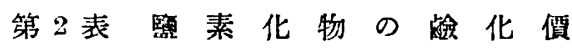

战佥 化 㵋

130.5 (战化時間 4)

150.6 ( " 4)

$180.2(\% 10)$
篮素化率(重量\%)

8.13

9.42

11.30

\section{2. 實噞方法}

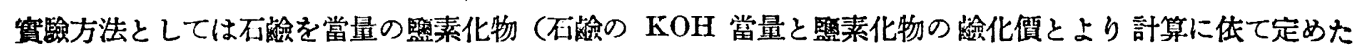
相當量) と共にフラスコに秤取し內容物が空氣に依て受ける酸化を防ぐためにブラスコ內に水素を通じつっ所 定溫度に保つた油槽中で加熱した後反應の進度を检した。若し內容物が完全にェステル化を起す時は次式の如 く進行すべきである。

$$
\begin{aligned}
& \mathrm{RCOONa}+\mathrm{R}^{\prime} \mathrm{Cl} \rightarrow \mathrm{RCOOR}+\mathrm{NaCl} \cdots \cdots \cdots \text { 一筑化物の場合 } \\
& x \mathrm{RCOONa}+\mathrm{R}^{\prime}(\mathrm{Cl})_{x \rightarrow(\mathrm{RCOO})} x \mathrm{R}^{\prime}+x \mathrm{NaCl} \cdots \cdots \text { 多整素化物の場合 }
\end{aligned}
$$

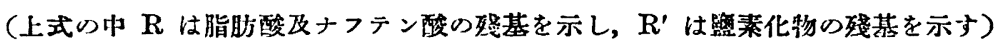

然し乍ら一方加熱反應中に䜿素化物の分解に依て $\mathrm{HCl}$ を生じ，これか石羷と反鷹して次式の如く遊離酸を 生ぜしめる。

$$
\mathrm{RCOONa}+\mathrm{HCl} \rightarrow \mathrm{RCOOH}+\mathrm{NaCl}
$$

又多監素化物の場合には部分的エステル化物（例へば $\left(\mathrm{RCOO}{ }_{n} \mathrm{R}^{\prime}(\mathrm{Cl})_{x-n}\right.$ )の生成も考へられるから結局反㕍 系中には RCOONa, $\mathrm{RCOOH}, \mathrm{R}^{\prime}\left(\mathrm{Cl}_{x} \mathrm{R}^{\prime} \mathrm{Cl} \text {, ( } \mathrm{RCOO}\right)_{x} \mathrm{R}^{\prime}, \mathrm{RCOOR}^{\prime},\left(\mathrm{RCOO}_{n}{ }_{n} \mathrm{R}^{\prime}(\mathrm{Cl})_{x-n}\right), \mathrm{NaCl}$ が存在する

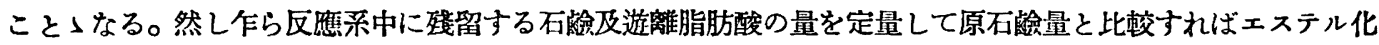
に㑈て消費された石䠯の量を知り得る翋である。それには最初に反應物の酸價を測定して遊離脂肪酸を石险と

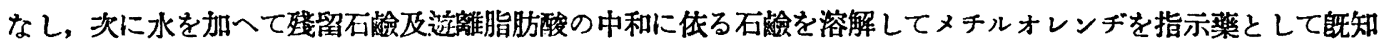

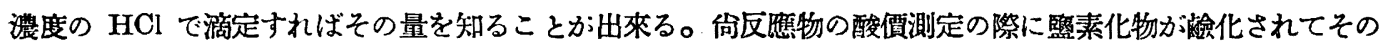
ためにも多少のアルカリが消費されるが，この際の生成物は $\mathrm{KCl}$ であるから $\mathrm{HCl}$ 滴定に体る不羭の定量に は何等支障を來たさない譯である。

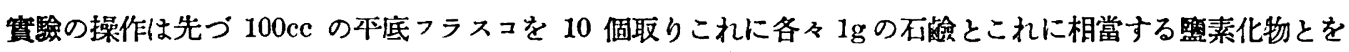
秤取し，各フラスコには 2 本のガラス管を搟入したコルク栓を施し（ガラス管は 2 本共內容物に接觸せしめ ず) 2 本のガラス管に依つて各フラスコをゴム管で並列に連結して一端より水素を送つてフラスュ內の空氣を 排除し得る樣にした。これらのフラスコ全體は一定溫度の油槽中で加熱し 1 時間每に試料フラスコを 1 個づ

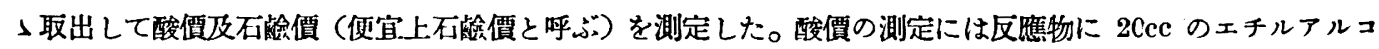
ールを加へてアルカリで滴定した。酸性物質を全部中和した後これに $80 \mathrm{cc}$ の水を加へて加溫して生成石踰並

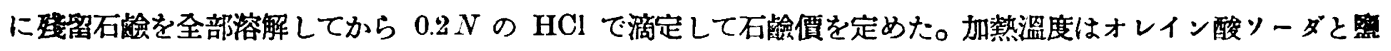
素化テトラリンに就ては $100^{\circ}, 120^{\circ}, 140^{\circ}$ 及 $160^{\circ} \mathrm{C}$ の各溫度で又他の試料に就ては $146^{\circ}$ 及 $166^{\circ} \mathrm{C} に$ 於てのみ 實驗を行つた。

\section{3. 實驗結果亚に其教察}
a. オレイン酸ソーダと㮌素化テトラリンとの反鷹 
第 3 表 $106^{\circ} \mathrm{C}$ に於ける反應

\begin{tabular}{|c|c|c|c|c|}
\hline $\begin{array}{l}\text { 反潐 } \\
\text { 時留 }\end{array}$ & 酸偵 & 石蔹偩 & エステル瑻 & $\begin{array}{c}\text { 反㮣率 } \\
(\%)\end{array}$ \\
\hline 0 & 9.7 & 183.1 & 0 & 0 \\
\hline 1 & 11.7 & 180.3 & 2.8 & 1.5 \\
\hline 2 & 12.7 & 177.5 & 5.6 & 3.1 \\
\hline 3 & 13.6 & 174.7 & 8.4 & 4.6 \\
\hline 4 & 13.6 & 174.7 & 8.4 & 4.6 \\
\hline 5 & 14.6 & 172.5 & 10.6 & 5.6 \\
\hline 6 & 14.6 & 171.8 & 11.3 & 6.2 \\
\hline 7 & 15.6 & 169.0 & 14.1 & 7.7 \\
\hline 8 & 15.6 & 163.0 & 14.1 & 7.7 \\
\hline 9 & 15.6 & 163.0 & 20.1 & 10.9 \\
\hline 10 & 16.0 & 163.0 & 20.1 & 10.9 \\
\hline
\end{tabular}

第 4 表 $120^{\circ} \mathrm{C}$ に於ける反應

\begin{tabular}{|c|c|c|c|c|}
\hline $\begin{array}{l}\text { 反應 } \\
\text { 時間 }\end{array}$ & 酸㵋 & 石䶨傾 & エステル瑻 & $\begin{array}{c}\text { 反應率 } \\
(\%)\end{array}$ \\
\hline 0 & 9.7 & 183.1 & 0 & 0 \\
\hline 1 & 15.6 & 177.5 & 5.6 & 3.6 \\
\hline 2 & 18.5 & 177.5 & 5.6 & 3.6 \\
\hline 3 & 19.5 & 174.5 & 8.4 & 4.6 \\
\hline 4 & 21.4 & 171.8 & 11.3 & 6.2 \\
\hline 5 & 24.4 & 171.8 & 11.3 & 6.2 \\
\hline 6 & 26.3 & 169.0 & 14.1 & 7.7 \\
\hline 7 & 27.0 & 167.5 & 15.6 & 8.6 \\
\hline 8 & 27.3 & 165.2 & 17.9 & 9.8 \\
\hline 9 & 27.3 & 161.4 & 21.7 & 11.6 \\
\hline 10 & 30.2 & 160.6 & 22.5 & 13.3 \\
\hline
\end{tabular}

第 5 表. $140^{\circ} \mathrm{C}$ に於ける反應

\begin{tabular}{|c|c|c|c|c|}
\hline $\begin{array}{l}\text { 反瞧 } \\
\text { 時問 }\end{array}$ & 酸㵋 & 石㣮㵋 & エステル㵋 & $\begin{array}{c}\text { 反䳟率 } \\
(\%)\end{array}$ \\
\hline 0 & 9.7 & 183.1 & 0 & 0 \\
\hline 1 & 20.8 & 171.8 & 11.3 & 6.2 \\
\hline 2 & 34.7 & 157.8 & 25.3 & 13.8 \\
\hline 3 & 35.7 & 157.8 & 25.3 & 13.8 \\
\hline 4 & 45.6 & 152.1 & 31.0 & 16.9 \\
\hline 5 & 55.5 & 152.1 & 31.0 & 16.9 \\
\hline 6 & 56.5 & 146.5 & 36.6 & 19.9 \\
\hline 7 & 65.4 & 140.8 & 42.3 & 23.1 \\
\hline 8 & 69.4 & 138.0 & 45.1 & 24.6 \\
\hline 9 & 73.4 & 132.4 & 50.7 & 27.7 \\
\hline 10 & 81.3 & 126.8 & 56.3 & 30.7 \\
\hline
\end{tabular}

第 6 表 $160^{\circ} \mathrm{C}$ に於ける反應

\begin{tabular}{|c|c|c|c|c|}
\hline 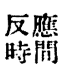 & 酸侕 & 石䶨傾 & エステル偩 & $\begin{array}{c}\text { 反袐率 } \\
(\%)\end{array}$ \\
\hline 0 & 9.7 & 183.1 & 0 & 0 \\
\hline 1 & 38.9 & 160.6 & 22.5 & 12.3 \\
\hline 2 & 58.5 & 154.9 & 28.2 & 15.4 \\
\hline 3 & 75.1 & 135.2 & 47.9 & 26.2 \\
\hline 4 & 90.6 & 135.2 & 47.9 & 26.2 \\
\hline 5 & 95.5 & 132.4 & 50.7 & 27.7 \\
\hline 6 & 107.2 & 129.6 & 53.5 & 29.2 \\
\hline 7 & 112.0 & 125.2 & 57.9 & 31.6 \\
\hline 8 & 116.9 & 122.6 & 60.5 & 33.0 \\
\hline 9 & 116.9 & 122.6 & 60.5 & 33.0 \\
\hline 10 & 一 & 一 & - & - \\
\hline
\end{tabular}

上揭諸表に對する說明並に考察 上表に示したェステル價とは原石险價剆ち反應時間 0 の時の石险價から反

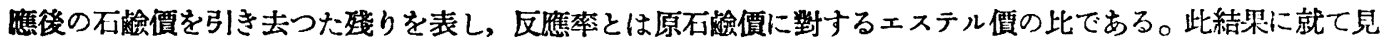

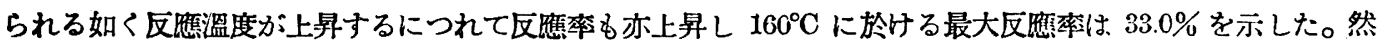
し此反焦率は或る極限があつて夫以上の加熱に传ても霬加しない樣である。之は多分加熱と同時に多量の遊離

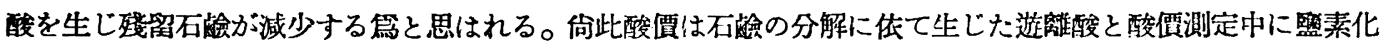
物が加水分解を受けて生ずる $\mathrm{HCl}$ との總和であるが後者に传る $\mathrm{KOH}$ の消費は比較的少いるのと思はれる。

b. オレイン酸ソーダと答素化テレビン油との反應

第 7 表 $140^{\circ} \mathrm{C}$ に於ける反應

\begin{tabular}{|c|c|c|c|c|}
\hline $\begin{array}{l}\text { 反㢈 } \\
\text { 時間 }\end{array}$ & 酸㵋 & 石哺㵋 & エステル㵋 & $\begin{array}{c}\text { 反應掏 } \\
(\%)\end{array}$ \\
\hline 0 & 5.7 & 183.1 & 0 & 0 \\
\hline 1 & 6.8 & 180.3 & 2.8 & 1.5 \\
\hline 2 & 11.7 & 169.0 & 14.1 & 7.7 \\
\hline 3 & 11.7 & 163.4 & 19.7 & 10.8 \\
\hline 4 & 17.5 & 154.9 & 28.1 & 15.4 \\
\hline 5 & 18.5 & 152.1 & 31.0 & 16.9 \\
\hline 6 & 24.4 & 149.3 & 33.8 & 18.5 \\
\hline 7 & 32.2 & 143.7 & 39.4 & 21.5 \\
\hline 8 & 32.2 & 146.5 & 36.6 & 20.0 \\
\hline 9 & 38.1 & 146.5 & 36.6 & 20.0 \\
\hline 10 & 38.0 & 140.8 & 42.3 & 23.1 \\
\hline
\end{tabular}

第 8 裴 $160^{\circ} \mathrm{C}$ に於ける反否

\begin{tabular}{|c|c|c|c|c|}
\hline $\begin{array}{l}\text { 反潐 } \\
\text { 䚄間 }\end{array}$ & 酸顀 & 石踰䨘 & エステル傾 & 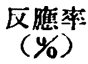 \\
\hline 0 & 10.9 & 183.1 & 0 & 0 \\
\hline 1 & 29.5 & 154.9 & 28.2 & 15.4 \\
\hline 2 & 51.4 & 135.2 & 47.9 & 26.2 \\
\hline 3 & 59.1 & 132.4 & 50.7 & 27.7 \\
\hline 4 & 62.4 & 123.9 & 59.2 & 32.3 \\
\hline 5 & 67.9 & 121.1 & 62.0 & 33.9 \\
\hline 6 & 70.0 & 121.1 & 62.0 & 33.9 \\
\hline 7 & 71.5 & 118.3 & 64.8 & 35.4 \\
\hline 8 & 72.6 & 118.3 & 64.8 & 35.4 \\
\hline 9 & 72.6 & 115.2 & 68.3 & 37.3 \\
\hline 10 & 72.6 & 115.2 & 68.3 & 37.3 \\
\hline
\end{tabular}




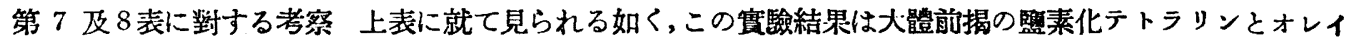
ン酸ソーダとの反應と類似の倾向が見られる。然しこの場合は酸價の壇加が比較的少く反應率も幾分大である。 c. オレイン酸ソーダと盟素化鑛油との反應

第 9 表 $140^{\circ} \mathrm{C}$ に於忛る反慰

\begin{tabular}{|c|c|c|c|c|}
\hline $\begin{array}{l}\text { 反隹 } \\
\text { 時間 }\end{array}$ & 酸㑯 & 石堽㵋 & エステル傾 & $\begin{array}{c}\text { 反㗹率 } \\
(\%)\end{array}$ \\
\hline 0 & 1.6 & 183.1 & 0 & 0 \\
\hline 1 & $4.4^{\prime}$ & 180.3 & 2.8 & 1.5 \\
\hline 2 & 6.6 & 177.5 & 5.6 & 3.1 \\
\hline 3 & 7.7 & 177.5 & 5.6 & 3.1 \\
\hline 4 & 8.8 & 174.7 & 8.4 & 4.6 \\
\hline 5 & 11.0 & 174.7 & 8.4 & 4.6 \\
\hline 6 & 11.0 & 174.7 & 8.4 & 4.6 \\
\hline 7 & 13.1 & 171.8 & 11.3 & 6.2 \\
\hline 8 & 24.5 & 171.8 & 11.3 & 6.2 \\
\hline 9 & 25.2 & 170.5 & 12.6 & 6.9 \\
\hline 10 & 29.6 & 170.5 & 12.6 & 6.9 \\
\hline
\end{tabular}

第 10 表 $160^{\circ} \mathrm{C}$ に於ける反磼

\begin{tabular}{|c|c|c|c|c|}
\hline $\begin{array}{l}\text { 反睢 } \\
\text { 時間 }\end{array}$ & 酸㵋 & 石瞼傾 & エステル債 & $\begin{array}{c}\text { 反鹰率 } \\
(\%)\end{array}$ \\
\hline 0 & 1.6 & 183.1 & 0 & 0 \\
\hline 1 & 8.8 & 177.5 & 5.6 & 3.1 \\
\hline 2 & 19.7 & 171.8 & 11.3 & 6.2 \\
\hline 3 & 38.3 & "I & "I & " \\
\hline 4 & 40.5 & "I & "I & "I \\
\hline 5 & 42.7 & " & " & " \\
\hline 6 & 45.9 & "I & "I & " \\
\hline 7 & 49.3 & 169.0 & 14.1 & 7.7 \\
\hline 8 & 53.6 & 166.0 & 16.9 & 9.2 \\
\hline 9 & 55.8 & 163.4 & 19.7 & 10.8 \\
\hline 10 & 60.2 & 160.6 & 22.5 & 12.3 \\
\hline
\end{tabular}

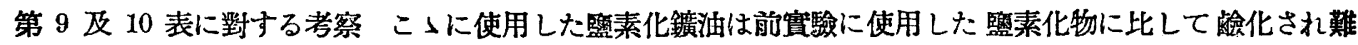
いものであつて, 最大嚝化價を得るには 10 時間以上の加熱を要したものである。著者は前實驗に於て見られ る如くテトラリン及テレビン油の整素化物は熱に不安定のため石畧との反㮣中に分解して $\mathrm{HCl}$ を生じ，これ が石勄に反應して遊離酸を生ぜしめる結果エステルの生成率が惡いのではないかと考へて比較的安定なこの盟

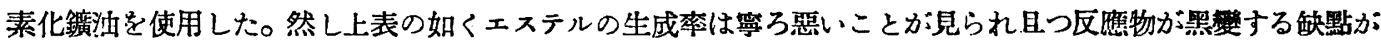
ある。

d. ステアリン酸ソーダと甍素化テトラリンとの反應

第 11 萃 $140^{\circ} \mathrm{C}$ に於计る反碓

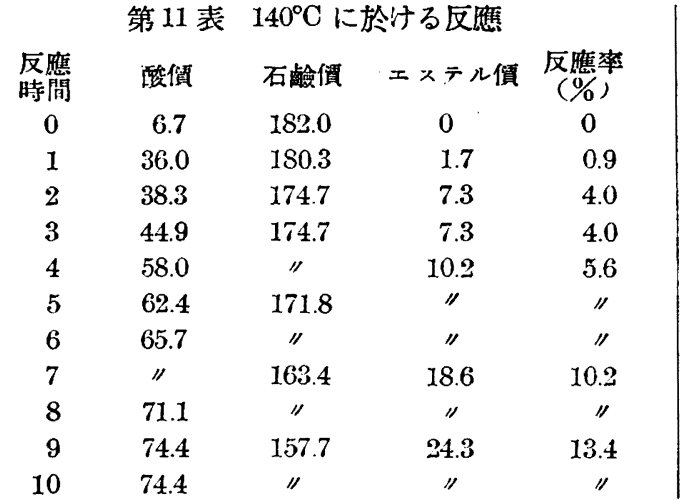

第 12 表 $160^{\circ} \mathrm{C}$ に於ける反應

\begin{tabular}{|c|c|c|c|c|}
\hline $\begin{array}{l}\text { 反噟 } \\
\text { 時間 }\end{array}$ & 酸鼬 & 石畧㵋 & エステル傎 & $\begin{array}{c}\text { 反應张 } \\
(\%)\end{array}$ \\
\hline 0 & 6.7 & 182.0 & 0 & 0 \\
\hline$x$ & 35.1 & 156.7 & 25.3 & 13.9 \\
\hline 3 & 47.7 & 153.9 & 28.1 & 15.4 \\
\hline 4 & " & " & " & " \\
\hline 5 & 57.5 & 150.5 & 31.5 & 17.3 \\
\hline 6 & 60.2 & "I & " & "I \\
\hline 7 & 73.0 & 147.2 & 34.8 & 19.1 \\
\hline 8 & 80.6 & 146.8 & 35.2 & 19.3 \\
\hline 9 & 85.2 & 143.7 & 38.3 & 21.0 \\
\hline 10 & 92.6 & 140.8 & 41.2 & 39.6 \\
\hline
\end{tabular}

上表に對する考察 ステアリン酸ソーダの場合にはオレイン酸ソーダに比して反應率が著しく劣つてるる。 而も酸價の增加は割合に大きい樣である。

e. ナフテン酸ソーダと盤素化テトラリンとの反應（第 13〜14 表）

第 13 及 14 表に對する考察 ナフテン酸ッーダも照素化テトラリンと反應して比較的良好なエステル生威

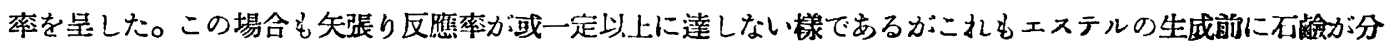
解するためであらう。 
第 13 表 $140^{\circ} \mathrm{C}$ に於ける反應

\begin{tabular}{|c|c|c|c|c|}
\hline $\begin{array}{l}\text { 反隹 } \\
\text { 時間 }\end{array}$ & 酸澬 & 石簽僧 & エステル谓 & $\begin{array}{c}\text { 反隼來來 } \\
(\%)\end{array}$ \\
\hline 0 & 7.6 & 157.8 & 0 & 0 \\
\hline 1 & 328 & 140.8 & 17.0 & 10.8 \\
\hline 2 & 35.0 & 138.0 & 19.8 & 12.5 \\
\hline 3 & 40.5 & 129.0 & 28.2 & 17.9 \\
\hline 4 & 44.8 & 126.0 & 31.0 & 19.6 \\
\hline 5 & 53.6 & 121.1 & 36.7 & 23.3 \\
\hline 6 & 54.8 & " & " & "I \\
\hline 7 & 64.7 & 112.7 & 45.1 & 28.6 \\
\hline 8 & ن5.6 & "I & " & "I \\
\hline 9 & 67.8 & 109.9 & 47.9 & 30.4 \\
\hline 10 & 70.0 & "I & " & " \\
\hline
\end{tabular}

4. 總
籍 14 表 $160^{\circ} \mathrm{C}$ に於ける反應

\begin{tabular}{|c|c|c|c|c|}
\hline $\begin{array}{l}\text { 反噟 } \\
\text { 時䦭 }\end{array}$ & 酸摆 & 石战俭 & エステル偩 & $\begin{array}{c}\text { 反應率 } \\
(\%)\end{array}$ \\
\hline 0 & 7.6 & 157.8 & 0 & 0 \\
\hline 1 & 45.9 & 135.2 & $\mathbf{2 2 . 6}$ & 14.3 \\
\hline 2 & 62.4 & 126.8 & 31.0 & 19.6 \\
\hline 3 & 73.3 & 115.4 & 42.4 & 26.8 \\
\hline 4 & 79.9 & 107.0 & 50.8 & 32.2 \\
\hline 5 & 84.3 & "I & " & 32.2 \\
\hline 6 & 91.9 & " & " & 32.2 \\
\hline 7 & 93.0 & 104.0 & 53.8 & 34.1 \\
\hline 8 & 107.3 & "I & "I & 35.4 \\
\hline 9 & 109.4 & 102.0 & 55.8 & 35.4 \\
\hline 10 & 116.0 & "I & "I & "I \\
\hline
\end{tabular}

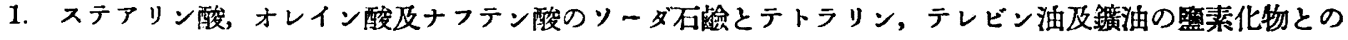
反應に依てどの程度のエステル化か起るかを觀察した。

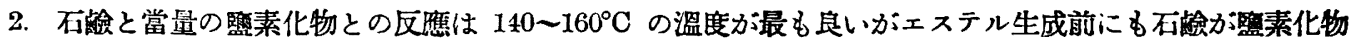
の分解で生じた $\mathrm{HCl}$ で分解されることも多いのでェステル生成率に限度がある。

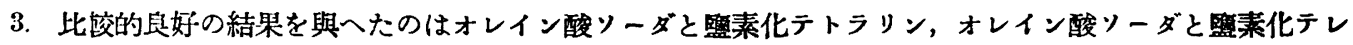
ビン油及ナフテン酸ソーダと䤈素化テトラリンとの反應である。

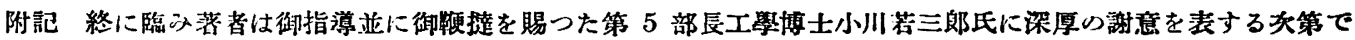
ある。

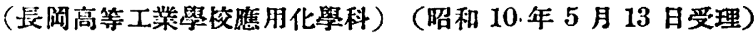

\section{4。難 燃 性 蛿 料の發熱量簡易測定法}

$$
\text { 鈴木 恪 雄 }
$$

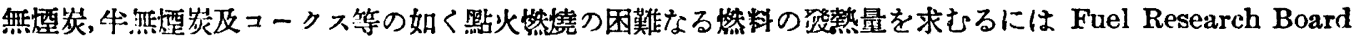
(Phys. Chem. Survey. Nat. Coal Resources, 1923，2，28)の如く高迡の酸素を用ひボンべ中にて㜣嬈せしむ るもの, Georg Lohmann 及 Max Mehler (Ger. 225,424, 1908), Max Mehler (Brit. 12,652, 1909) の如く 酸素氣流中に燃燒せしむるものあり。叉 Fuel Research Board（前出)の如く發熱量烁知の重滑油を加ふるる

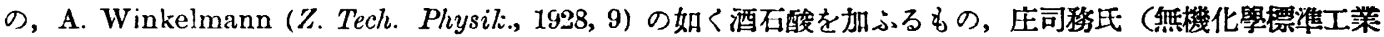
分析法)の如く發等量形知の石炭を加ふるものあり。酸素を供給する物體は上記の如く酸素的身の場合あり。 Parr 氏は過酸化ソーダを用ひ，Lewis Thompson 氏は硝酸カリと照酸カリの $1: 3$ の混合物を用ひたり。又 R. Vondracek (Brennstoff Cikem., 19:7，8) 等の如くその化學組成より慜熱量を算出するすのあり。之等の中

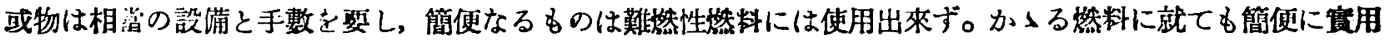
上の發熱量を求め得られざるかと考へて本研究を行ひたり。

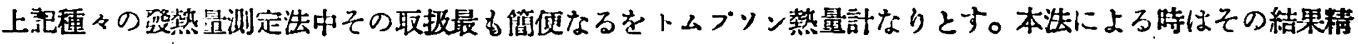

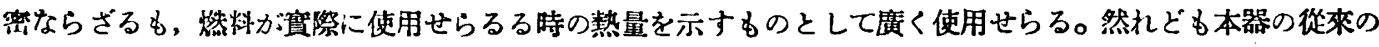

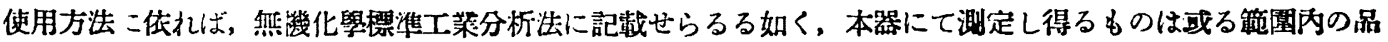

